\title{
Legal update
}

\section{Evaluating database right}

\section{Ewan Nettleton}

is a solicitor in the intellectual property department at Bristows. He specialises in intellectual property law. He has an MA in chemistry and a D.Phil in protein chemistry. He is particularly interested in matters relating to the IT and pharmaceutical industries.

\section{Sam Tuxford}

is a trainee solicitor at Bristows. He has a M.Eng in civil engineering and is currently in the commercial intellectual property department.

\begin{abstract}
Database right is a relatively new intellectual property right which offers protection to European databases over and above the protection provided by copyright and other legal rights. The European Commission has recently released its evaluation report on the Directive which brought database right into being five years ago. The findings of the report, and in particular its assessment of whether the desired upturn in European database production and narrowing of the gulf between the US and European database industries has been achieved, are considered below. The Commission's suggestions on how databases should be protected going forward are also considered.
\end{abstract}

\section{INTRODUCTION}

The Database Directive $(96 / 9 / \mathrm{EC})^{1}$ was first implemented in European member states in 1998 and introduced a new intellectual property right, so-called 'database right', specifically directed at databases. As regular readers of the Journal will be aware, the scope of protection offered by this relatively fledgling right is still being determined by the Courts with several high-profile cases being fought, some all the way up to the European Court of Justice (ECJ).

At the end of 2005, some four years later than the Directive required, ${ }^{2}$ the

Ewan Nettleton Bristows

3 Lincoln's Inn Fields London WC2A 3AA UK

Tel: +44 (0) 207400 8000; Fax: +44(0) 207400 8050; e-mail: ewan.nettleton@ bristows.com
European Commission published its first evaluation report on the Directive. This was drawn from a survey of 500 European organisations involved in the database industry and from information received from the Gale Directory of
Databases, which reportedly covers over 15,000 databases and database products in all subjects produced worldwide by more than 4,000 database producers offered by around 3,000 online services and database vendors and distributors. Surprisingly, the Commission's report ran to a mere 27 pages.

One of the most notable aims of the Directive, which is stated explicitly in its introductory provisions, was to close the gap that was perceived to exist between the information markets of the EU and US by stimulating the production of databases in Europe. The Commission's report assesses whether this, and whether the other objectives of the Directive, have been met and makes proposals for changes to the regime for database protection going forward.

This article takes a critical look at the 
findings of the report, with an emphasis on whether the Directive has achieved the aim of stimulating database creation in Europe and on how database right is perceived by those in the database industry.

\section{THE AIMS OF THE DATABASE DIRECTIVE}

The report summarises the aims of the Directive as follows:

1 To eliminate the differences in the legal protection of databases across Europe;

2 To stimulate database creation by means of a sui generis right (ie by the new intellectual property right database right - introduced by the Directive);

3 To safeguard the legitimate interests of manufacturers and lawful users; and

4 To increase EU database production as compared with the US.

The first aim of the Directive recognised that before the Directive's implementation there were significant variations in the levels of protection given to database owners across Europe. By the introduction of database right (and also by harmonising the protection afforded to databases by database copyright), it was hoped that the Directive would achieve harmonisation and a more consistent level of protection. The third aim recognised the need to protect the rights of lawful users of databases to access information and the balance that has to be struck between the legitimate interests of database manufacturers and the rights of database users.

By contrast, the objectives two and four were unashamedly concerned with promoting the production of databases in Europe and closing the gap with the USA. As explained previously, ${ }^{3,4}$ the USA is generally thought to offer less protection to databases and database right is concerned mainly with databases created in Europe; there are question marks over whether companies from the USA and other non-EEA countries can own or acquire database right. It was therefore thought that if database right afforded sufficient protection and was recognised as a strong right by database producers, the database industry would be promoted in Europe compared with the US.

\section{HAVE THE AIMS OF THE DIRECTIVE BEEN MET?}

The Report considers each of the above aims in turn. The Commission's findings are described in the next sections.

\section{Harmonisation of the legal protection of databases}

The Commission confirmed that all 25 Member States of the European Union have now transposed the Directive into national law, (albeit most after the 1998 implementation deadline and some only by as late as 2003), and that it has also been implemented in the EEA countries (Iceland, Liechtenstein and Norway). As with any directive, however, there can be variation in the ways in which the provisions are implemented by individual member states and the ways in which the national courts apply them.

Although the national courts have consistently interpreted the definition of a 'database' widely, as the Commission intended, the report acknowledges that case law from across the member states has also highlighted significant textual ambiguities in the terms used to define the protection conferred by database right. In particular, the Commission notes the variation in interpretation of the 'substantial investment' required for the databases to benefit from protection. 
For example, whilst, in the Netherlands, the District Court of The Hague has held that the costs of collecting together and maintaining up-to-date information on several thousand real estate properties did amount to a 'substantial investment', the President of the District Court of Rotterdam in Holland has held that newspaper headlines were a mere 'spin-off' of the newspaper's principal business of publishing its papers and therefore did not contribute to the 'substantial investment' required. ${ }^{6}$ Other issues where divergent case law was identified include the extent of protection that exists in relation to exploitation of on-line databases and internet-related activities such as hyper-linking and deep-linking using search engines. Perhaps unsurprisingly in light of these differences, the on-line survey conducted by the Commission revealed a perception in the industry that as things stand, protection is not totally harmonised throughout Europe; 31 per cent of respondents believe that big gaps between the protection provided in several countries still remain.

The report also discusses the implications of the rulings on database right handed down by the ECJ in November 2004. As described in earlier articles $^{7-9}$ the ECJ significantly curtailed the scope of database right in British Horseracing Board (BHB) v William Hill and Fixtures Marketing cases by, in particular, restricting what may constitute 'substantial investment'. ${ }^{10}$ As the report notes, in relation to the BHB's database of horseracing runners and riders the ECJ stated that:

The resources used to draw up a list of horses in a race and to carry out checks in that connection do not constitute investment in the obtaining and verification of the contents of the database in which that list appears.

(Emphasis taken from the report.)
In doing so, the ECJ drew a distinction between investment made in creating the materials which comprise a database's contents, and obtaining pre-existing materials in order to assemble them into a database. The former could not constitute investment of the type required but the latter could. Whilst, as the report notes, this may not stop database creators in some industries such as publishers of directories, listings or maps - from benefiting as long as they obtain their data from others rather than create it, other industries - such as real estate or employment agencies where data is 'created' and concurrently stored and processed in a database are in a weaker position. The position for marketing databases and the extent to which they are protected will depend on how the databases are created, but marketing databases created by companies for sale to others are at present more likely to be protected than internal marketing databases created as part of a company's ongoing business.

Notably, the Commission states that the drawing of this distinction between creating data and obtaining it went against its original intention of protecting databases by database right in a wide sense, suggesting that this distinction was not something the Commission had envisaged. As the report notes, the ECJ's rulings also demonstrate the difficulties involved in attempting to harmonise national laws by recourse to the 'untested and ambiguous' legal concepts involved in putting in place a new intellectual property right such as database right.

\section{Safeguarding the legitimate interests of manufacturers and lawful users}

The Commission reports positively on this issue, suggesting that: '.. most rightholders (mainly, publishers) believe that the Directive safeguards the balance 
of interests of rightholders and users'. It acknowledges, however, that the two-tier approach of the Directive, by which databases can potentially be protected by both database right and (if sufficiently creative) database copyright, may have caused confusion amongst certain users, those in academic and scientific circles in particular. Notably, the Commission suggests that the ECJ in its judgment in the William Hill and Fixtures Marketing cases may have been influenced by a fear that the balance between users and rightholders was too far in the rightholder's favour. The ECJ's interpretation may, the report suggests, go some way to allaying the fears of those who believe that the Directive could lock up otherwise publicly available information in a way that would stifle research and innovation because it has significantly curtailed the scope of protection.

\section{Has the Directive stimulated database creation and closed the EU/USA divide?}

When the proposals for the Directive were first adopted in 1992, the report notes, it was estimated that whilst 25 per cent of accessible online databases were of western European origin, 56 per cent came from the USA. Between 1992 and 2001, there was a gradual increase in the number of database entries for western European databases in the Gale directory, rising from 1,838 to 4,085 . There are limitations to what can be interpreted from these empirical data, however, and with the advent of new technologies such as internet and digital services during that time, database production was in any case on the rise. Furthermore, after 2001, the number of western European databases dropped, according to Gale, and by 2004 the number was back to more or less the same level as in
1998, the very year the Directive had to be implemented.

In the circumstances, and because most member states were several years late in implementing the Directive, it is unsurprising that the report concludes that the Directive 'has had no proven impact on the production of databases'.

Interestingly, the increased number of western European databases between 1992 and 2001 also made inroads into North America's share. According to Gale, whilst the western European share of global database production increased from 22 per cent to 34 per cent, North America's share fell from 69 per cent to 60 per cent. This trend has since been reversed, with North America's share rising to 72 per cent and western Europe's dipping down to below its 1992 level. Additionally, whilst the Commission's online survey suggests that most respondents believed that database right had helped Europe to catch up with the USA in terms of investment, most considered it had not helped significantly to improve the global competitiveness of the European database sector.

For these reasons, the Commission's overriding conclusion was that the economic impact of database right on bridging the gap between Europe and the USA remains unproven.

\section{POSSIBLE WAYS FORWARD}

Faced with these largely disappointing findings, the Commission's report sets out four possible ways forward.

\section{Option one: Repeal the Directive}

This would allow member states to revert back to the national laws which applied prior to their adoption of the Directive, with protection of databases provided by copyright and other means such as the law of contract. This seems to be an unlikely option however, with 
the Commission noting that repealing the Directive would remove the harmonising effects of the Directive on database copyright and also meet 'considerable resistance' from the EU database industry.

\section{Option two: Withdraw database right}

Whilst this would remove database right as an intellectual property right, meaning copyright and other means would have to be relied upon, it would still maintain the harmonising effects of the Directive on database copyright. Whilst the Commission's comments on this option suggest it is more favoured than complete withdrawal of the Directive, the report acknowledges that European publishers and database producers would clearly prefer database right to remain.

\section{Option three: Amend the Database right provisions}

Amendment of the Directive could be attempted to clarify issues such as the protection given where data are created, collected and screened concurrently, and what is meant by 'substantial investment'. As the Commission notes, however, attempts at clarification could introduce another layer of 'untested legal notions' that might not withstand scrutiny by the ECJ.

\section{Option four: Maintain the status quo}

Despite the perceived limitations of the Directive, the Commission considers that maintaining the status quo may be justified if only on grounds of cost, particularly as the ECJ's rulings mean (according to the Commission) that database right is now only available to 'primary' producers of databases and not to those for whom databases are a 'secondary' activity.

\section{CONCLUSION}

Whilst it is difficult to say which of these four starkly different options will be taken, the tone of the Report and the way the options are presented suggests the Commission favours the lattermost, perhaps with some limited clarification of certain issues by amendment. The fact that the report suggests database right has been accepted if not welcomed by most respondents to the Commission's survey, combined with the time and costs involved in its removal, suggest to the authors that database right is here to stay.

(C) Bristows

\section{References and notes}

1 Directive 96/9/EC of the European Parliament and of the Council of 11 March, 1996 on the legal protection of databases.

2 Article 16(3) of the Directive required a report on the Directive's application be submitted by the Commission to the European Parliament, the Council and the Economic and Social Committee by the end of 2001 .

3 Nettleton, E. and Obhi, H. (2004) 'Legal protection for databases in Europe: The vexed question of whether US businesses can benefit', Journal of Database Marketing \& Customer Strategy Management, Vol. 11, No. 3, pp. 268-273.

4 Nettleton, E and Obhi, H. (2004) 'Legal protection of databases: A wider transatlantic divide?', Journal of Database Marketing \& Customer Strategy Management, Vol. 12, No. 1, pp. 80-86.

5 NVM v. De Telegraaf; judgment of 12 September, 2000.

6 Algemeen Dagblad ao v. Eureka; judgment of 22 August, 2000.

7 Nettleton, E. and Obhi, H. (2005) 'ECJ rules on protection afforded by database right', Journal of Database Marketing \& Customer Strategy Management, Vol. 12, No. 3, pp. 266-271.

8 Nettleton and Obhi (2004) op. cit. pp. 80-86.

9 Obhi, H. and Nettleton, E. (2004) 'Database right - Place your bets', Journal of Database Marketing \& Customer Strategy Management, Vol. 11, No. 4, pp. 373-378.

10 The British Horseracing Board and Others $v$ William Hill Organisation Ltd. Judgment of the Court (Grand Chamber), 9 November 2004, Case C-203/02, and the associated cases involving Fixtures Marketing, C-46/02, C-444/02 and C-338/02, in which judgments were handed down on the same day. 